\title{
Internalization of Cultural Values in Schools Early Steps in Building Nation Characters
}

\author{
Suriadi $^{1}$, Mursidin $^{2}$ \\ Doctoral Student Program UIN Maulana Malik Ibrahim Malang, Indonesia ${ }^{1}$ \\ Doctoral Student Program UIN Antasari, Banjarmasin, Indonesia ${ }^{2}$ \\ \{suriadi@iaisambas.ac.id $\left.{ }^{1}, \underline{\text { mursidinsambas@gmail.com }}{ }^{2}\right\}$
}

\begin{abstract}
This article discusses the internalization of school cultural values in realizing character education. The research aims to try to describe the internalization of school cultural values in a) curriculum and learning management, b) student management, c) management of educators and education personnel in realizing character education - this study designed with a qualitative approach using a case study design. The research subjects were principals, educators, educational staff and students of Sambas IC. The results of the analysis show that the habituation of values such as religious values, honesty, togetherness, simplicity, and discipline that are systematically and sustainably integrated in curriculum management, management of students and administration of educators and education personnel, will create character education that gives birth to a generation that superior and emotionally intelligent, socially intelligent and spiritually intelligent. An excellent production with multiple intelligences is an essential provision in preparing children for the future because someone who has many intelligences will be more comfortable and more successful in facing all kinds of life challenges, including in building a nation with character.
\end{abstract}

Keywords: Internalization, School Culture, Character Value.

\section{Introduction}

Attention to educators and characters is also a concern of the government, proclaimed several regulations in the form of rules, including Instructive President of the Republic of Indonesia Number 1 of 2010 concerning Acceleration of Implementation of National Development Priorities which mandate program was strengthening methodology and curriculum based on cultural values and national character. The issuance of this policy is a continuation of the duties and responsibilities of the government as mandated by Article 31 paragraph 3 of the 1945 Constitution and the objectives of national educators listed in Article 3 of Law No. 20 of 2003g concerning the National Education System. [1] The development of cultural education and character of the nation was then clarified with the issuance of several policies, including through the national policy formulation on "Development of Culture and Nation Character (School Guidelines) in 2010 and for pilot schools in 2011. 
Zamroni provides a limitation that school culture is a pattern of values, principles, traditions, and habits that are formed in the long journey of the school, developed by the school for a long time and become a handle and are believed by all school people to encourage emergence attitudes and behavior of school people. [2] School residents according to Law number 20 of 2003 concerning the national education system consist of students, educators, principals, educators, and school committees. One of the subjects taken in the cultural research of this school is students.

character education, which is one of the current Indonesian government programs, must be explored and built on Indonesian culture so that the character that is the desired goal indeed has an Indonesian style. [3] therefore, in-depth studies are needed to support and strengthen government programs through research at Madrasah Aliyah NegeriInsanCendekiaSambas, West Kalimantan.

\section{Literature review}

\subsection{Internalisi.}

The term internal love was initially applied in psychology in the psychoanalytic field, this can be seen as expressed by WW Meissner in his book Psychoanalysis Internalization as follows:"My exploration of internalization processes originally stemmed from an interest in the problem itself and an awareness of the looseness and dissatisfactory state of psychoanalytic formulationon the subject. More recently, however, I have become convinced that the issue of internalization lies at the very heart of contemporary psychoanalytic concerns" [4]

The internal process as understood from the definitions mentioned above is very subjective because the quality of the transformed thing is not always the concrete, real and accessible thing, but also the things that are abstract in terms of ideas. For this reason, the result of the hint internalization process is complicated to know for sure, because it depends on the individual's appreciation of transformed values. When talking about this internal process, it is clear that the environment is the main factor for the formation of personal love. This means that this internal love process will not be formed without the context that significantly affects life and personality formation. [5]

Based on the description of the definition of personal love above, it can be understood that internal love is a process of transforming values, spirits, teachings or doctrines that someone has to others so that the values reflect and in turn fall into the self and belong to them as the results of the internalization process.

\subsection{School Culture}

Some strategies that can be applied in the integration implementation of education are in the education process, namely through the curriculum, learning, leadership, student activities, and school culture. According to Wagiran integrating education in school, religion is the most effective effort, considering that useful values will be more accessible through example and habituation in everyday life. [6] Therefore, understanding and values are needed which will color the lives and trainees of the school community. Cultural approaches to improve school performance will be more effective compared to structural approaches. An artistic approach with a focus on the culture of excellence by emphasizing changes in the thoughts, words, attitudes, actions, and hearts of every schoolchild. Education which done formally is almost 
pastoral and will not hit the target because the dispute of the student is not well built so that his mind is not open and not ready to accept the values offered. [6]

Thus school culture is the pattern of dominant values supported by schools or philosophy that guide school policies towards all elements and components of the school including education stakeholders, such as how to implement work in schools and underlying assumptions or beliefs adopted by school personnel. School culture refers to a system of values, beliefs and norms that are shared collectively, and implemented with full awareness as a natural behavior, which is formed by the environment created by the same understanding among all, elements and personnel of the school, both to the school, the teacher, staff, students and if necessary form the opinion of the same community as the school.

\subsection{Character}

Arismantoro, which states that style is different from personality because personality notions freed from value. Nonetheless, both personality (nature) and physical, behavioral characteristics aimed at the social environment, both are relatively permanent and guide, mobilize and organize individual activities. A person can be called a person of character (if someone has style) if his behavior is by moral rules. [7]

According to Adeyemi, in a study entitled Teaching Character Education in the Curriculum and the Role of the Junior Secondary Level in Botswana, it stated that in enhancing character education in schools, all stake-holders others also have a role in promoting character education in schools and the wider community. [8] Also, the components of knowledge, namely the contents of the curriculum for learning processes, volunteering, school management, the implementation of activities and ethics, and the whole neighborhood of the school can grow good characters. [9]

\section{Method}

This study uses a qualitative research approach with a case study design. The reason for using the qualitative approach is that in this study the main focus is on the internal values of school culture in realizing character education, it is a process, event or activities of a person (some people) in revealing substantiation and truthfulness in research, so that profound observation is needed with a natural setting to comprehend social phenomena or symptoms comprehensively and contextually by describing empirical reality about the object under study

The approach and design of the research are used, then the instrument used to collect the data is the research itself. The presence of researchers in qualitative research is a must. Because this type of research prioritizes observational findings conducted by researchers in the natural setting of the study directly. The research was done at Province Kalimantan Barat by taking place at the Cendekiah Negeri Aliyah Madrasah Sambash West Kalimantan. The study depth directed to aspects of managing curriculum and learning, leading students and managing educators and education staff.

The research uses qualitative data in the form of words, behavior or policies of each school culture actor, data contained in documents, manuscripts, notes, and others, which deny the school's cultural values. Data sources in qualitative research can be obtained from key informants who are the main actors of the object being studied related to the internal wisdom of the school's cultural values - principal as the primary source of data (key informant). To determine the informants, the researchers used sampling (especially key informants) by purposive sampling, which was then developed into other information using a snowball 
sampling technique. To obtain data, the researcher uses techniques that collect data that are validly used in qualitative research. It is common knowledge that in qualitative research uses data collection techniques such as in-depth interviews, participatory observation, and documentary studies.

The research based on observing and short interviewing does not automatically mean that it can be said to be qualitative because the qualitative researchers are also interpreting the beliefs and behaviors of the participants. Referring to the opinion above, the primary data obtained will be analyzed according to the interactive model following the instructions of Miles \& Huberman, namely (1) data reduction, (2) data presentation and (3) conclusions (temporary conclusions, verification, and conclusions).[9]

\section{Result and discussion}

\subsection{Internal School Value Evaluation on Curriculum Management and Learning}

Curriculum content of each level of education is adjusted to the development of students; national curriculum content is the standard that must be implemented in steps to realize the competent standards of student participants, the Regional Government strives to develop the competency standards of student participants to achieve learning outcomes based on established national standards. In the 2003 National Education System Law article 1 paragraph $19 \mathrm{~h}$ explains that curriculum is a set of plans and arrangements regarding the objectives, contents, and learning materials and the methods used to guide the implementation of learning activities to achieve certain educational goals.

Based on this curriculum is used in Sambas MAN IC West Kalimantan which is a developmental form of the curriculum of Madrasah Aliyah which nationally refers to under the curriculum of the Agamah Republic Indonesian Ministry of Religion. The kind of development is done based on the vision and mission in the IC MAN Sambas West Kalimantan, which is adjusted to the needs of student learning development. Therefore in the curriculum, there are changes or modifications, reduction and transfer of student learning hours. The structure of this curriculum is expected to be able to provide new learning processes and support the operation of character building in students as in the contents of the madrasa's vision and mission which is "Manifesting Quality Human Resources Dayah High in faith and piety, mastering Knowledge and Technology and actualizing it in society."

The curriculum of the curriculum in MAN IC Sambas is a blend of the national curriculum of the religious and content ministries of the curriculum which was modified by the madrasa itself. This combination is intended to facilitate madrasahs in implementing or internalizing the cultural values of character formation, whether in implementing intrusive learning or in teaching and learning activities in the classroom, curricular activities or extracurricular activities.

In general, the curriculum in MANh IC Sambash for general subjects refers to the curriculum of 2013 at the Madrasahh level of the Ministry of Education and Culture (Kemendikbudh) while Islamic themes as a hallmark of madrasahs are based on the curriculum of the madrasa set by the Ministry of Religion, including Al Quran Hadith, akhlak, fiqh and history of Islamic culture. The local content is Tahfidzh. The subject explicitly has direct material on the effort to establish morality, which in addition to being elaborated on the internalization of other issues, then the content of the learning values is described in life behavior in the madrasa, both in the learning process and in a peaceful life. These curriculum contents and development are outlined in a document book on how to organize madrasahs that 
in MANH IC Sambash West Kalimantan implement the national curriculum set by the modified government by the Vision, for example, the goals and targets of the madrasa. The curriculum modification was in the form of strengthening the basic concepts of science and technology mastery and the typical curriculum in the field of equality.

Curriculum management with the content of cultural values is critical, as stated by Khan and Law, Regarding the lack of sizes, types or origins, curriculum and heart, and soul of all educational institutions. Lamentably, it is a widely recognized notion in academics that the approach to development is integrated into minimum and isolated factors such as institutional leadership, social trends, industry factors and the role of the government. [10] Learning is carried out interactively, it is fun, interactive, challenging, motivating and giving space for the creativity of the child and the independence of the child according to the potential, the interest of the father and the need to grow optimally. Curriculum development puts forward the experience of student participants through the process of practicing, asking, reasoning, and trying (observation based learning), which is supported by active participation by good people, mass media and the environment around them.

The curriculum that is currently taking effect in MAN IC Sambas in each subject has listed the value values that form the basis of character formation. Costs are included in the core competencies of each subject matter. The core competency is included in the lesson plan planned by the instructor responsible for the subject matter. The expected goal is that after learning about each material, the student is expected to have an understanding and ability to carry out the values in daily life. $\mathrm{H}$ The values supposed to be derived from the core competencies are, religiously as in KI1, social cyclical costs include honesty, discipline, responsibility, caring, courtesy, environmental friendliness, cooperation, peace of mind, responsiveness and proactive in $\mathrm{KI} 2$, knowledge value to $\mathrm{KI} 3 \mathrm{~h}$, and there is value for independence in KI4. As Suparno stated, one of the approaches to curriculum education is to integrate values in each subject and therefore become the responsibility of all teachers. [11]

The internal costs of schooling in the process of teaching and learning have always become commonplace in the IC IC Sambas, West Kalimantan. Before the teaching and learning activities began, some businesses were no longer foreign to the madrasa community. The program for the formation of members in Sambas IC is well programmed. Before entering school hours are cultivated for tahfidz Quran from 06.30 to 07.00 , this activity is carried out routinely every morning before coming subjects except Monday because there are direct instructions. Tahfidzh is done to make it easier to memorize the Al Quran of the students, is done repeatedly and continuously, besides that, the Maghrib prayer completed, and the study is led by thunder because something done routinely will make it easier to memorize and make it a habit that forms culture.

Likewise, by reciting a prayer before the subject begins and praying after it is finished, this applies to all questions, not just habituation but it hoped that students and teachers of the matter still rely on all their efforts to Allah SWT and have the blessing of learned knowledge. Thus, internalizing religious values in the learning activities always goes well and becoming a culture of is no longer a necessity in Sambas IC MAN.

Management Curriculum is an effort to manage curriculum in a good school, in this relationship management must be directed so that the learning process can run well, the benchmark is how the achievement of goals by students as a result of the learning process, according to Satori, tasks covered in the field curriculum is a) Organizing the formulation of the objectives of the curriculum, b). Organize this (content), curriculum composition and organization, c) Connect the curriculum with time, physical facilities and available personnel, 
d) Organize materials, resources, and equipment for teaching programs, e) Organize supervision teaching.

\subsection{Internal education of school values in Student Management}

Various types of activities were designed and cultivated in life at the MAN IC Sambas in West Kalimantan to grow the value of the fundamental values as implied in the vision and mission of the school. The primary benefit that will be built according to the idea is to realize high-quality Human Resources in faith and piety, master science and technology and be able to actualize it in society. This vision is then described in various forms of student activities in all aspects of life in Sambas MAN IC both in dormitory life and in extracurricular activities in the shade of students or that have been programmed by the School of Organizations to realize the formation of character education.

The guidance of the development of the students and the students in the Sambas IC became a particular concern, starting from the reception system, advice to the process of observation. The critics of student acceptance in Sambas IC MAN beside considering academic achievement from their original schools, they also find other abilities which are full of religious values. This is due to the consideration that students' accomplishments and results must be respected, and at Sambas Sambas IC IC they have the authority to facilitate and develop these capabilities.

Participants in the new student who have accepted at Sambas IC MAN will be identified, mapped and developed with necessary capabilities with the match program. Matriculation gave to new students for four weeks aiming to explore the ability of new students related to the potential possessed which is behind the middle school students. Besides this matriculation activities aim to develop the necessary skills of specific subject areas, introduce learning facilities and media and the teaching and learning process. This was done to make it easier for students in addition to undergoing the teaching and learning process as well as the initial capital in moral formation in Sambash IC MAN. Outside of the intrusive hours, the parties at the Sambas Sambas MAN IC have designed a schedule of activities that will be a guideline for students to carry out their actions in the context of the Sambas IC MAN. Based on the table of events, it can be interpreted that the Sambas MAN IC West Kalimantan has designed the best possible time, no wasted time is useless, all filled with useful activities to develop the personality of students. The content of material content is loaded with the content of the Islamic religion as an ideologue is embraced in school. The preparation of the agenda of student activities is based on the needs of the development of the personality of the students, especially in the formation of student character.

Determination of student agendas outside of the co-curricular hours to make use of every available time by adjusting to the activities of the Islamic people worship. The list of this student is expected to become a daily patron for students so that a cultural process is formed by planting the values of madrasah as the fundamental values that have determined together, namely religious values, independence, discipline, commitment, simple life, and honesty. The process of cultivating this value is undoubtedly taken care of by socialization. Socialization of cultural values is an important thing to do so that students have the same understanding as the madrasah about the amount that will be developed and how the process of implementation. This process of socialization is carried out by the madrasa both in the form of delivery during the teaching and learning process in the classroom, official events such as in ritual as well as in hostel life. 
The activities of moral formation, especially the creation of Islamic values are the main focus in IC Sambas. As conveyed by Pembinah teacher, "the most basic thing is to familiarize our children to always pray five times, meaning not only praying, but obligatory prayer, we expect the habituation to planted, so that it continues, so hear the prayer immediately for prayer congregation, because if you are accustomed to congregation then it will take care of your faith ". This shows that Sambas MAN IC strongly emphasizes the planting of religious values on students, both those that have obligatory worship and sunnah worship. This habituation is always planted in various aspects, whether in dear life, learning activities or outside of campus or mingling with the community around to transmit the knowledge they have.

The activities of planting Islamic values continue to take place in Sambash IC MAN. At certain moments such as the holy month of Ramadan, the intensity of their worship is intensified, such as tadarus Al-Qur' every time five prayers are finished, they also perform the dhuha prayer, and there are also evening preaching before 5 o'clock until the iftar study, a kind of da'wah. Also, every Monday and Thursday students are required to carry out the Sunnah. They also conduct hygiene competitions and the beauty of rooms, organize and coordinate the provision of infaq and zakat and social services to help poor communities.

Education character will be necessary or essential in the formation of national quality character, which does not ignore social values such as tolerance, togetherness, cooperation, mutual help and Sensormatic and so on. Education character will give birth to a superior person who not only has cognitive abilities but has the style that can realize success.

\subsection{Educator management and education staff in realizing education character}

Strengthening the character of the teaching and education staff of MAN IC Sambas West Kalimantan received serious attention from the Ministry of Religion and the internal madrasa itself. This strengthening and guidance have been established from the start, starting from the recruitment of human resources. MANIC Sambas has strong standards for character development values that are used as a priority in the reception of educators and education staff. The rules of educators and education personnel needed as general qualifications to accepted as educators and education personnel are; Islam, ethical, physical and spiritual health, high commitment, able to read the Koran smoothly, have ICT skills (information and communication technology) and not sue cases in court.

To improve the competency of the Human Dayah Source to carry out its primary tasks, the MAN IC Sambas refers to "the basic values of the work culture of employees" from the Ministry of Religion, namely integrity, professionalism, innovation, responsibility and exemplary. This is the basis of development and guidance for educators and educational staff in the MAN IC Sambas. Madrasa also always carry out activities that are renewing or improving insight into thunder, usual programs in the form of training, workshops or meetings between teachers. These activities are part of the madrasa program always to update and improve the knowledge and competence of education personnel in MAN IC Sambas. Madrasas routinely conduct insight development activities for educators. Teacher's insight development activities involve all the teachers and boarders in the MAN IC Sambas West Kalimantan, which are carried out internally at the MAN IC Sambas and always bring in speakers from outside, both by education experts and from the Ministry of Religion from Province and Regency. In addition to the training activities, activities that have been cultivated related to character building in MAN IC Sambas are in the form of routine studies. As expressed by the head of Madrasah that the school always conducts a survey every Friday 
morning, activities in the study model and the rotating teacher bring the material, but during the Ramadhan, study review period is seminal and is replaced with the "Safari Ramadhan" studies. The Friday study is a study that is routinely carried out every week and has been cultivated at MAN IC Sambas since it was warm. This study is called as a form of spiritual refreshment for teachers and employees.

Other routine activities that have been cultivated and are characteristic of building character values in MAN IC Sambas are in the form of family gathering. The operation of a kind of family gathering was a place to strengthen friendship and kinship relations for the citizens of IC Sambas, specifically the thunder, employees and their families. In these activities, the madrasa students always get enlightenment because in every event they are always accompanied by the spiritual shower or in the form of material that can arouse enthusiasm to practice role as educator and role model for families and students.

Thunder and employees in Sambas IC are examples of character formation. So that thunder must be an influential figure to positively influence students, both in the context of learning in the classroom and life outside the school. In the process of learning mainly in curriculum 2013, the teacher is an essential figure in facilitating to be a facilitator for students. If then this pattern can be carried out well by thunder, then there are some habituation values that can form characters if carried out continuously in the learning process, including habituation values, among others, overriding students' curiosity, responsibility, discipline, and selfconfidence. In addition to figures in the teacher class, the role of foster parents is also given. The formation of foster caregivers or in this case is carried out by the cleric of an ustad and female teacher which is the guidance of students in a family that is given individual responsibility in fostering students 5 to 7 students per person. Asuh coach is a substitute for senior for female teacher students. Like parents at home, foster parents have a significant role in the formation and development of children, both in terms of academic growth and mental development. All forms of problems faced by students in Islamic schools become part of the responsibility of full foster parents.

\section{Conclusion}

Character education is the whole process of learning experienced by students as an experience of personality formation through understanding and experiencing one's values, virtues of morality, typical values of religion, and moral values. To form a characterized human being, it must always be sought out, to be able to identify the excellent character and shape the nature of love, and habituation in carrying out good morals so that it is not only behavior but indeed becomes an inherent character.

The best way to internalize character education in schools is through a holistic approach that integrates character development into every aspect of school life. School vision is the central element that will guarantee the continuity of character education. The concept and mission of the school will give birth to cultural values which will then be elaborated in the management of the school, including the control of curriculum and learning, supervision of students and administration of teaching staff and education. Internalization of the school's cultural values in curriculum and learning management must be compiled in the form of a curriculum of integration which includes curriculum, non-academic curriculum. The content of the curriculum reflects the cultural values of the school such as religious values, social values, honesty, simplicity, and independence. Success in organizing, and cultivating the values of life through character education can also be influenced by the way or approach used in conveying knowledge. It is also necessary to have thunder characterized as an example to 
produce students with character. The integration between the right and continuous curriculum and its supporting elements is the key to the success of character education that forms a characterized nation that has its own culture and culture of the government.

\section{References}

[1] I. Afiful and I. J. Dian, "Introduction to the Islamic Education Concepts (an Integral Paradigm Building Efforts)," in Proceedings International Seminar on Islamic Law, Economic, Education, and Science, Fakulti Tamadun Islam, UTM Malaysia, 2014, pp. 136-147.

[2] Presiden Republik Indonesia, Undang-Undang Sisidiknas No 20. Tahun 2003 Tentang Sisitem Pendidikan Nasional. 2003.

[3] Zamroni, Pendidikan Demokrasi pada Masyarakat Multikultural. Yogyakarta: Gavin Kalam Utama, 2011.

[4] Suriadi, "Integration of Islam and Local Culture to Build Character Education in Early Childhood," in International Conference on Islamic Education (ICIED), 2017.

[5] W. W. Meissner, "Internalization and object relations," J. Am. Psychoanal. Assoc., vol. 27, no. 2, pp. 345-360, 1979.

[6] Wagiran, "Developing technical vocational education and training (TVET) student character throught school culture," in Seminar Nasional IKA UNY di UNY, 2011.

[7] K. Y. S. Emmanuel, "Pendidikan Nilai Kebangsaan Melalui Budaya Sekolah di SMA Taruna Nusantara Dan SMA Kolese De Britto," J. Pembang. Pendidik. Fondasi dan Apl., vol. 3, no. 2, pp. 142-150, 2015.

[8] Arismantoro, Character Building: Bagaimana Mendidik Anak Berkarakter. Yogyakarta: Tiara Wacana, 2008.

[9] M. B. Adeyemi, Tshiamiso Violet Moumakwa, and D. A. Adeyemi, "Teaching character education across the curriculum and the role of stakeholders at the junior secondary level in Botswana," Stud. Home Community Sci., vol. 3, no. 2, pp. 97-105, 2009.

[10] A. Ikhwan, "Sistem Kepemimpinan Islami: Instrumen Inti Pengambil Keputusan pada Lembaga Pendidikan Islam," Istawa Jurnal Pendidik. Islam, vol. 3, no. 2, pp. 111-154, 2018.

[11] B. M. Matthew and H. A.Michael, "Qualitativeh Datah Analysish:," in A Sourceh Bookh of New Methodes, Newbury Park: C.A.Sage, 1994. 